Abstract-Abundance of harbor porpoise (Phocoena phocoena) was estimated from data collected during vessel surveys conducted throughout the inland waters of Southeast Alaska. Line-transect methods were used during 18 seasonal surveys spanning 22 years (1991-2012). Estimates were derived from summer surveys only because of the broader spatial coverage and greater number of surveys during this season than during other seasons. Porpoise abundance varied when different periods were compared (i.e., 1991-1993, 2006-2007, and 2010-2012); however, persistent areas of high porpoise densities occurred in Glacier Bay and Icy Strait, and off the town of Wrangell and Zarembo Island. Overall abundance of harbor porpoise significantly declined from the early 1990 s $(N=1076,95 \%$ confidence interval $[\mathrm{CI}]=910-1272)$ to the mid2000s $(N=604,95 \%$ CI $=468-780)$. This downward trend was followed by a significant increase in the early 2010s ( $N=975,95 \%$ CI $=857-1109$ ) when abundance rose to levels similar to those observed 20 years earlier. Potential factors that could contribute to the downward trend were examined. The 2 regions with high densities of harbor porpoise (i.e., Glacier Bay and Icy Strait as well as Wrangell and Zarembo islands), that were consistently occupied by this species, and the different trend values of these 2 regions indicate that some fine-scale population structuring may exist for harbor porpoise inhabiting the inland waters of Southeast Alaska.

Manuscript submitted 14 May 2014. Manuscript accepted 25 March 2015. Fish. Bull 113:242-255 (2015).

Online publication date: 14 April 2015. doi: 10.7755/FB.113.3.2

The views and opinions expressed or implied in this article are those of the author (or authors) and do not necessarily reflect the position of the National Marine Fisheries Service, NOAA.

\title{
Temporal changes in abundance of harbor porpoise (Phocoena phocoena) inhabiting the inland waters of Southeast Alaska
}

\author{
Marilyn E. Dahlheim (contact author)' \\ Alexandre N. Zerbini' ${ }^{1} \mathbf{2}$ \\ Janice M. Waite ${ }^{1}$ \\ Amy S. Kennedy ${ }^{1}$ \\ Email address for contact author: marilyn.dahlheim@noaa.gov \\ 1 National Marine Mammal Laboratory \\ Alaska Fisheries Science Center \\ National Marine Fisheries Service, NOAA \\ 7600 Sand Point Way NE \\ Seattle, Washington 98115-6349 \\ 2 Cascadia Research Collective \\ 2181/2 West Fourth Avenue \\ Olympia, Washington 98501
}

Harbor porpoise (Phocoena phocoena) are distributed throughout Alaska waters (Fiscus et al. ${ }^{1}$; Leatherwood and Reeves, 1978; Leatherwood et al. ${ }^{2}$; Lowry et al. ${ }^{3,4}$; Dahlheim et al., 2000, 2009; Hobbs and Waite, 2010), commonly inhabiting waters less than 100 m deep (Barlow, 1988; Carretta et al., 2001; Hobbs and Waite, 2010). Currently, 3 stocks of harbor porpoise are recognized in Alaska: 1)

\footnotetext{
${ }^{1}$ Fiscus, C. H., H. W. Braham, R. W. Mercer, R. D. Everitt, B. D. Krogman, P. D. McQuire, C. E. Peterson, R. M. Sonntag, and D. Withrow. 1976. Seasonal distribution and relative abundance of marine mammals in the Gulf of Alaska, 238 p. Northwest Fish. Sci. Cent. Processed Rep., [Available from Alaska Fish. Sci. Cent., Natl. Mar. Fish. Serv., 7600 Sand Point Way NE., Seattle, WA 98115.]

${ }^{2}$ Leatherwood, S., A. E. -Bowles, and R. R. Reeves. 1983. Endangered whales of the eastern Bering Sea and Shelikof Strait, Alaska. Results of aerial surveys April 1982 through April 1983 with notes on other marine mammals seen. Hubbs Sea World Research Institute Technical Report No. 83-159, 315 p. [Available from the Natl. Mar. Mamm. Lab., Alaska Fish. Sci. Cent.,7600 Sand Point Way NE., Seattle, WA 98115.]
}

the Southeast Alaska stock-occurring from Dixon Entrance $\left(54^{\circ} 30^{\prime} \mathrm{N}\right.$; $\left.134^{\circ} 00^{\prime} \mathrm{W}\right)$ to Cape Suckling $\left(60^{\circ} 00^{\prime} \mathrm{N}\right.$; $\left.\left.144^{\circ} 00^{\prime} \mathrm{W}\right), 2\right)$ the Gulf of Alaska stock-occurring from Cape Suckling to Unimak Pass, and 3) the Bering Sea stock-occurring throughout the Aleutian Islands and all waters north of Unimak Pass (Allen and Angliss, 2012). The boundaries of these 3 stocks are based on geography and

${ }^{3}$ Lowry, L. F., K. J. Frost, and J. J. Burns. 1982. Investigations of marine mammals in the coastal zone of western Alaska during summer and autumn. Annual report on contract NA 81 RAC0050, submitted to NOAA, Outer Continental Shelf Environmental Assessment Program, Juneau, Alaska, 37 p. [Available from the Natl Mar. Mamm. Lab., Alaska Fish. Sci. Cent.,7600 Sand Point Way NE., Seattle, WA 98115.]

${ }^{4}$ Lowry, L. F., K. J. Frost, D. G. Calkins, G. L. Swartzman, and S. Hills. 1982. Feeding habits, food requirements, and status of Bering Sea marine mammals. Vol. 1. Final report submitted to the North Pacific Fishery Management Council, Anchorage, Alaska, 292 p. [Available from the Natl. Mar. Mamm. Lab., Alaska Fish. Sci. Cent.,7600 Sand Point Way NE., Seattle, WA 98115.] 
perceived areas of low porpoise density, but to date there has been no analysis of genetic or individual movement to assess the validity of these designations.

The preference of harbor porpoise for shallower waters makes them highly vulnerable to incidental capture during net-fishing operations (Jefferson and Curry, 1994; Read, 1994; Barlow et al., 1995). The nature and magnitude of incidental takes are currently unknown but could be significant in some gill-net and purseseine fisheries targeting Alaska salmon (Oncorhynchus spp.) and Pacific herring (Clupea pallasi).

Obtaining abundance estimates for harbor porpoise, a small, inconspicuous cetacean species, is challenging. For example, the ability to detect harbor porpoise is highly sensitive to environmental conditions; surveys should be limited to relatively calm sea states and good lighting conditions. Despite such challenges, estimates of both density and abundance for this species do exist for Alaska waters. Taylor and Dawson (1984) reported on a shore-based study that yielded density estimates for Glacier Bay National Park and Preserve. In 1991-1993, and again in 1997-1999, aerial surveys of coastal waters in Alaska, ranging from the southeastern Bering Sea to Dixon Entrance, yielded more recent abundance estimates (Dahlheim et al., 2000; Hobbs and Waite, 2010).

In this study, we report the results from dedicated line-transect surveys conducted to determine the density and abundance of harbor porpoise in Southeast Alaska over a 22-year period from 1991 through 2012. The objectives of these surveys were 1 ) to obtain relative abundance estimates of harbor porpoise within the inland waterways of Southeast Alaska, 2) to investigate porpoise density and abundance by different strata (i.e., smaller regions), 3) to establish a baseline for detecting changes in harbor porpoise abundance through time, and 4) to report on significant insights on this species as a result of these investigations.

\section{Materials and methods}

\section{Study area}

The study area included the inland waters of Southeast Alaska (Fig. 1). Surveys covered all major channels or bays from Juneau to Ketchikan: Lynn Canal, Icy Strait, Glacier Bay, Cross Sound, Chatham Strait, Stephens Passage, Frederick Sound, Sumner Strait, and Clarence Strait. When time permitted or weather precluded the surveying of major channels, many adjacent smaller bodies of water (bays, inlets, and passages) were surveyed. The coverage of these smaller areas varied considerably among surveys and across the years.

\section{Field methods (1991-1993)}

During 1991-1993, surveys were carried out aboard the NOAA Ship John N. Cobb, a $28.4 \mathrm{~m}$ long research vessel with a combined bridge and average observer height of $5.9 \mathrm{~m}$. A line-transect method was employed to survey predetermined tracklines. At the start of this study, distribution, habitat preferences, and seasonal occurrence of harbor porpoise within the study area were unknown. Tracklines were designed throughout the study area with either a zig-zag or straight-line path, depending upon the size of the different areas. The survey was designed to include all major waterways and a selection of smaller bays and inlets to examine both deepwater and nearshore habitats throughout the entire study area. The same trackline design was employed for all surveys completed between 1991 and 1993, although alterations were made during some surveys depending on weather and other unforeseen circumstances (e.g., mechanical breakdowns or engagement in rescue operations).

During line-transect surveys, sighting data were collected by a team of 3 observers, with 1 observer at each of 3 stations: starboard, port, and recorder station. In the early $1990 \mathrm{~s}$, the total number of biologists participating in the survey was 6 ; therefore, a full observer rotation took $2 \mathrm{~h}$, with each observer spending $40 \mathrm{~min}$ at each station or watch, followed by a 2 -h rest period for each observer after each full rotation of watches. Schedules for observer rotations were selected randomly each day.

Port and starboard observers used $7 \times 50$ Fujinon $^{5}$ binoculars (model 56A2, Fujifilm Holdings Corp., Tokyo) to search from $0^{\circ}$ (at the ship's bow) to $90^{\circ}$. Scanning techniques were standardized with nearly $32 \mathrm{~min}$ (or $80 \%$ ) of the 40 -min watch spent scanning with the binoculars and about 8 min spent scanning with the naked eye. To reduce observer fatigue, binoculars were supported by adjustable metal poles that were either handheld or rested on the observer's hips. When not entering data, the recorder searched for porpoise by scanning both sides of the ship from the bridge with the naked eye. Binoculars were only used by the recorder to confirm sighting identifications and numbers. Sightings made by the officers, crew, and off-watch observers were recorded as "off effort" and were not used in calculations of density estimates.

A GPS unit was connected directly to a portable computer on the bridge. The date, time, and position of the ship were automatically entered into a data file every $10 \mathrm{~min}$ and whenever data were entered by the recorder. Search effort was recorded on the computer by marking the beginning and end of each transect. Beaufort sea state, a weather description (rain and fog), a visibility index, and observer positions (port, recorder, and starboard) were also entered. A new entry was made whenever a change in course, weather, or personnel occurred.

When a sighting was made, the recorder entered the following data: all sightings made by the port and starboard observers, the sighting angle, number

\footnotetext{
${ }^{5}$ Mention of trade names or commercial companies is for identification purposes only and does not imply endorsement by the National Marine Fisheries Service, NOAA.
} 


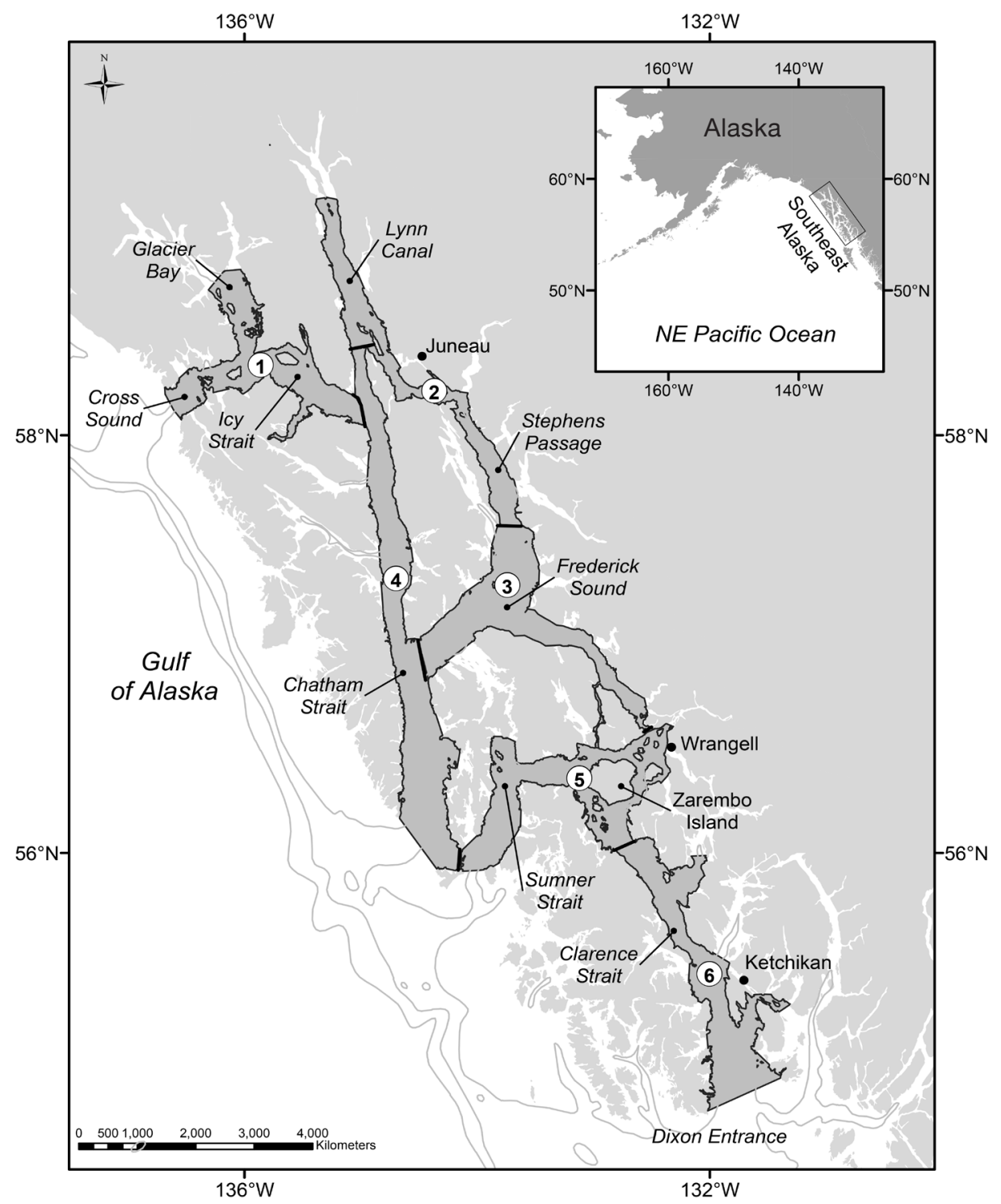

Figure 1

Map of study area in Southeast Alaska, with regions (strata), identified by numbers, where line-transect surveys of harbor porpoise (Phocoena phocoena) were conducted from vessels in inland waters over the periods1991-1993, 20062007, and 2010-2012.

of reticles to the sighting, radar distance (in nautical miles) to the shoreline at the same angle of the sighting, the species sighted, the number of individuals seen (best, high, and low counts), and the direction of travel of the animal(s). The sighting angle was obtained from peloruses mounted on the port and starboard bridge. To obtain distance to a sighting, Fujinon binoculars equipped with internal reticles were used. The top reticle was placed on the horizon or shoreline, and the number of reticles down to the location of the sighting was counted to the nearest tenth of a reticle. The reticle binoculars were calibrated with the ship's radar to objects of known distances.

\section{Field methods (2006, 2007, and 2010-2012)}

When line-transect surveys resumed in 2006 and 2007 aboard the John N. Cobb, it was recognized that there was considerable patchiness in the distribution and variation in density of harbor porpoise throughout the inland waters of Southeast Alaska, such that assigning a single density estimate to the whole study area was not appropriate. Consequently, smaller regions (strata) were established that were characterized by different geographic features: bays; inlets; deepwater channels, such as Icy Strait and Chatham Strait; and large areas of exposed waters, such as Frederick Sound. Allocation of stratum-specific effort by region was based on harbor 
porpoise densities derived from the results of the surveys conducted in 1991-1993. Regions with higher porpoise density in the early 1990s than other regions within the same period were given greater trackline effort in the later surveys. As in the early years, both zig-zag and straight-line paths were used for tracklines in an effort to include as many different habitats as possible.

Between 2010 and 2012, the following 4 charter vessels were used to conduct our surveys: July 2010, the FV Steller (21.3-m commercial fishing vessel with a combined bridge and observer height of $4.8 \mathrm{~m}$ ); September 2010, the FV Northwest Explorer (43.8-m research and fishing vessel with a combined bridge and observer height of $5.6 \mathrm{~m}$ ); June and September 2011, the Alaska Department of Fish and Game's RV Medeia (33.5-m research vessel with a combined bridge height and observer height of $7.4 \mathrm{~m}$ ); and July 2012, the RV Aquila (50.0-m commercial fishing vessel with a combined bridge and observer height of $7.2 \mathrm{~m}$ ). Different vessels were used because the John N. Cobb was decommissioned in 2008.

During all line-transect surveys, a team of 3 researchers ( 1 recorder and 2 observers) were on effort at any given time. However, the total number of biologists participating in a survey varied and determined the amount of time that observers spent off effort. The surveys conducted in 2006 and 2007 comprised 4 biologists, allowing 1 researcher to be off effort while the others manned stations. A full observer rotation took $1.5 \mathrm{~h}$, during which each observer spending $30 \mathrm{~min}$ at each station. In this case, the observer only had a rest period of 30 min between watches. To minimize fatigue, we also went off effort for meals, a schedule that provided each observer with an additional rest period. In 2010, 5 biologists participated in the survey. As with the 2006 and 2007 surveys, a full observer rotation took $1.5 \mathrm{~h}$ with a 1 -h rest period between watches. In 2011 and 2012, a full complement of 6 biologists participated in the surveys, allowing observers to spend 30 min at each station and have a 90 -min rest period. As noted earlier for the surveys conducted during 19911993, schedules of observer rotations were selected randomly each day.

To gather positional and navigational information, the computer used for data collection was either interfaced directly to the ship's GPS system (2006 and 2007) or connected to a portable GPS unit (2010-2012). The computer program WinCruz (R. Holland, NOAA Southwest Fisheries Science Center) was used to record all sighting and environmental data (e.g., cloud cover, wind strength and direction, and sea conditions). All other field methods for data collection (e.g., scanning techniques and field equipment) were the same as those used for surveys conducted in the early 1990s.

\section{Analysis for corrected distances}

For the surveys conducted during 2006-2012, distance from the vessel to the animal was originally recorded in WinCruz under the inherent assumption that the reticle given by the observer was taken from the horizon. However, within the inland waterways of Southeast Alaska, many of the sightings occurred against the land versus the true horizon. In these instances, the observer used the shoreline as their "horizon," and the distance to the sighting needed to be recalculated.

Sightings were recorded in WinCruz as the position of the observer (vessel) at the time of a sighting. All sightings were plotted in ArcMap, vers. 10.1 (Esri, Redlands, CA), and a line representing the distance to the real horizon, at the correct sighting angle, was drawn. The horizon line was truncated wherever it crossed land. The length of this new line, representing the distance from the observer to the shore at the angle of the sighting, was then converted to "reticles to land" with the DistRet function in Geofunc (National Marine Mammal Laboratory, website, accessed January 2013), a Microsoft Excel add-in that performs trigonometric calculations for plane and spherical geometry pertinent to marine mammal survey sighting methods (the appropriate formulas are described in Lerczak and Hobbs [1998]), to account for the corresponding observer height and radians per reticle for $7 \times 50$ binoculars. The resulting value of reticles to land was added to the original observer reticles to calculate the actual reticles of the animal from the vessel. Final distance from the observer to the animal was calculated from this new reticle value with the DistRet function. During the 1991-1993 surveys, observers obtained a distance to shore at the angle of the sighting from the ship's radar; however, to be consistent with distances calculated for sightings in the later surveys, the above protocol also was applied for all harbor porpoise sightings for those years.

\section{Line-transect estimation of density and abundance}

The density and abundance of harbor porpoise was estimated for 3 survey periods, 1991-1993, 2006-2007, and 2010-2012, and effort was allocated in 6 strata that were defined on the basis of distribution of harbor porpoise throughout Southeast Alaska and the configuration of different water features (such as large straits and bays). Data were pooled across sequential years as a strategy to minimize variability due to the spatial distribution of harbor porpoise and the allocation of survey effort, therefore, providing more robust estimates of abundance for the 3 different periods.

Previous studies reported no evidence of seasonal changes in distribution for harbor porpoise occupying the inland waters of Southeast Alaska (Dahlheim et al., 2009). Therefore, given the broader spatial coverage and greater number of surveys conducted in summer, we chose to derive abundance estimates from the summer season only.

\section{Estimation of detection probability}

Often, when the collection of sighting data is consistent across years or strata in visual line-transect sur- 


\section{Table 1}

Details about the 18 line-transect surveys for harbor porpoise (Phocoena phocoena) conducted from vessels in the inland waters of Southeast Alaska in 1991-2012 during spring, summer, and fall seasons.

\begin{tabular}{lllcc}
\hline Year & Season & \multicolumn{1}{c}{ Survey dates } & $\begin{array}{c}\text { Number of } \\
\text { days surveyed }\end{array}$ & Vessel \\
\hline \multirow{2}{*}{1991} & spring & 20 April-3 May & 14 & NOAA Ship John N. Cobb \\
& summer & 15-25 July & 11 & John N. Cobb \\
& fall & 12-25 September & 14 & John N. Cobb \\
1992 & spring & 29 April-12 May & 14 & John N. Cobb \\
& summer & 11-24 June & 14 & John N. Cobb \\
& fall & 10-23 September & 13 & John N. Cobb \\
1993 & spring & 30 April-13 May & 14 & John N. Cobb \\
& summer & 7-20 June & 14 & John N. Cobb \\
2006 & spring & 1-11 May & 11 & John N. Cobb \\
& summer & 7-17 July & 11 & John N. Cobb \\
2007 & spring & 19-28 April & 10 & John N. Cobbb \\
& summer & 7-17 July & 10 & John N. Cobb \\
2010 & fall & 10-20 September & 10 & FV Steller \\
& summer & 19 July-1 August & 14 & FV NW Explorer \\
2011 & fall & 9-22 September & 14 & RV Medeia \\
2011 & summer & 1-14 June & 14 & RV Medeia \\
2012 & fall & 25 August-7 September & 14 & RV Aquila \\
& & 7-20 July & 14 & \\
\end{tabular}

veys, perpendicular distance data are pooled to obtain a single detection function for the whole study period and area, and that pooled detection function is then used to compute annual or stratum-specific abundance estimates (e.g., Hammond et al., 2002; Barlow, 2006; Zerbini et al., 2006). In the present analysis, to minimize variability between survey periods that could lead to biased estimates of this parameter because of the temporal changes in survey protocols described above, detection probabilities $(P)$ were estimated for each period by pooling perpendicular distances for the periods 1991-1993, 2006-2007, and 2010-2012 separately. Detection probability was estimated by modeling ungrouped data of perpendicular distances that were truncated at $2 \mathrm{~km}$ by using both conventional distance sampling (CDS) and multiple covariate distance sampling (MCDS) approaches (Buckland et al., 2001; Marques and Buckland, 2003). The two methods differ in that MCDS allows for the inclusion of environmental covariates in the estimation of detection probability (Innes et al., 2002; Marques and Buckland, 2003).

Models were proposed to investigate the effects of covariates on $P$, and the models included group size as continuous covariates with year and Beaufort category as factor covariates. The Beaufort category had 2 levels: a "low" sea state (Beaufort 0-2) and a "high" sea state (Beaufort $>3$ ). In addition, a "ship" covariate was proposed for the period 2010-2012 to assess whether the use of ships with different height platforms had an effect on detection probability. This covariate had 4 levels, namely 1 level for each ship used during the summer surveys.

For each year, covariates were tested singly or in additive combination. It was expected that $P$ was positively correlated with group size and platform height but negatively correlated with Beaufort sea state. If a proposed model was inconsistent with these expectations, then that model was deleted from the analysis before model selection was performed (e.g., Zerbini et al., 2006). The model with the lowest Akaike's information criterion (AIC) was used for statistical inference (Burnham and Anderson, 2002). In the estimates provided here, the probability of detecting porpoise on the trackline was assumed to be unity $(g(0)=1$; see Discussion section).

\section{Estimation of group size}

Porpoise were considered to be in a group when animals were within 10-15 body lengths of each other. Group size has the potential to affect estimates of $P$. If larger groups are easier to detect further away from the trackline, then use of average group size can bias estimates (Buckland et al., 2001). In our exploratory analysis, regression of group size versus detection probability (Buckland et al., 2001) indicated that detections were independent of group size. Therefore, stratum-specific simple means were used after trunca- 
Table 2

Regions identified within the study area with overall size of each stratum and the amount of survey effort realized during line-transect surveys for harbor porpoise (Phocoena phocoena) conducted in summer in Southeast Alaska in 3 survey periods (1991-1993, 2006-2007, and 2010-2012).

\begin{tabular}{clrrrr}
\hline & & & \multicolumn{3}{c}{ Survey effort (km) } \\
\cline { 3 - 5 } Region & Region name & Area $\left(\mathrm{km}^{2}\right)$ & $1991-1993$ & $2006-2007$ & $2010-2012$ \\
\hline \multirow{2}{*}{1} & Cross Sound, Icy Strait, and Glacier Bay & 2302 & 1210 & 522 & 1122 \\
2 & Lynn Canal and Stephens Passage & 1985 & 740 & 345 & 526 \\
3 & Frederick Sound & 2951 & 1059 & 579 & 1279 \\
4 & Upper and Lower Chatham Strait & 4267 & 957 & 354 & 694 \\
5 & Sumner Strait, Wrangell, and Zarembo Island & 2943 & 812 & 450 & 1136 \\
6 & Clarence Strait to Ketchikan & 3218 & 533 & 159 & 599 \\
Total & & 17,665 & 6228 & 2466 & 6172
\end{tabular}

tion to estimate the expected group size for analysis conducted with CDS models. For MCDS models, estimates of the expected group size were obtained as proposed by Marques and Buckland (2003, Eq. 16 on p. 928).

\section{Estimation of abundance}

Stratum-specific abundance was estimated with the most supported detection probability model for each period. Total abundance in the survey regions was estimated by summing across the estimates of each individual stratum. Abundance and variance were estimated as in Innes et al. (2002) and Marques and Buck- land (2003). Lognormal 95\% confidence intervals (CIs) (Buckland et al., 2001) were computed for abundance estimates for each period.

\section{Results}

Between 1991 and 2012, 8 line-transect surveys were completed during the summer in Southeast Alaska (Table 1). The regions (or strata) within the study area are depicted in Figure 1. Total and stratum-specific regions and realized survey effort are summarized in Table 2. In all regions combined, a total area of $17,665 \mathrm{~km}^{2}$ representing $14,865 \mathrm{~km}$ of survey trackline was surveyed.
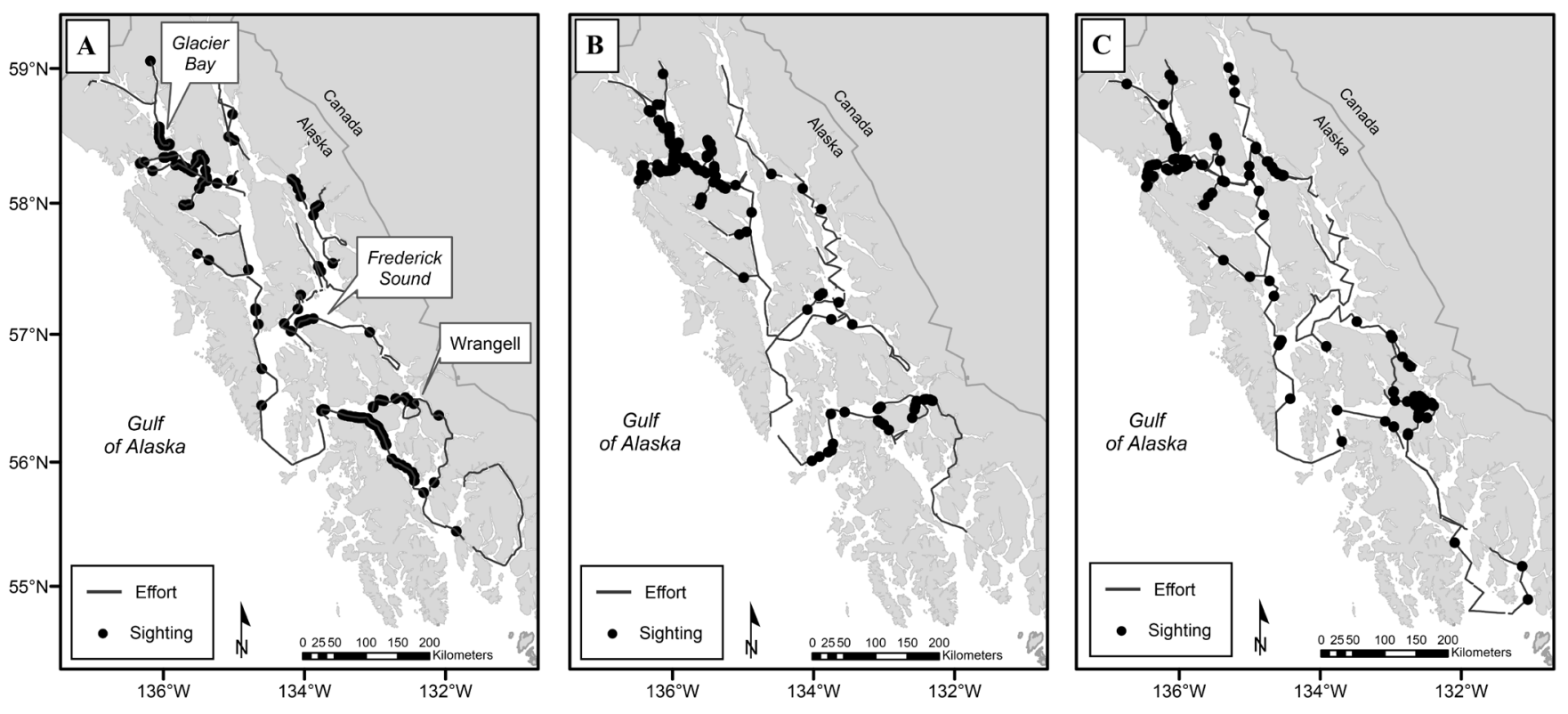

Figure 2

Sightings of harbor porpoise (Phocoena phocoena) and completed tracklines for line-transect surveys conducted in the inland waters of Southeast Alaska during summer in (A) 1991, (B) 1992, and (C) 1993. 

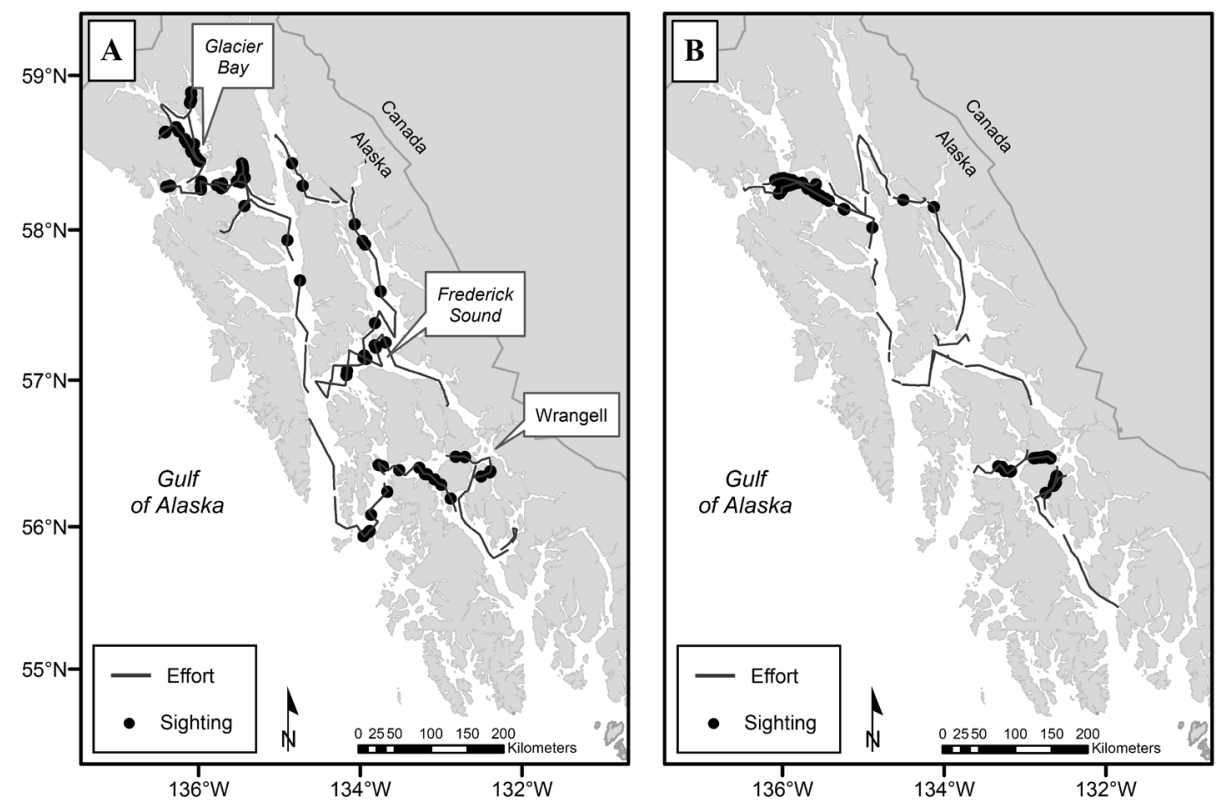

Figure 3

Sightings of harbor porpoise (Phocoena phocoena) and completed tracklines for linetransect surveys conducted in the inland waters of Southeast Alaska during summer in (A) 2006 and (B) 2007.

Completed tracklines and harbor porpoise sightings are depicted for each of the 3 periods in Figures 2-4.

\section{Estimation of detection probability}

Parameter estimates for the models most supported by AIC for each period are presented in Table 3, and their equivalent detection functions are illustrated in Figure 5. Estimation of $P$ varied between 0.47 (coefficient of variation $[C V]=0.04)$ and $0.61(C V=0.04)$. The halfnormal model with a Beaufort category covariate was selected as the best fit for the periods 1991-1993 and 2010-2012, and the hazard rate model without covariates was the most supported model in 2006-2007.

\section{Encounter rates and estimation of group size}

Sightings and group encounter rates are presented in Table 4. The total number of harbor porpoise groups seen in inland waters in Southeast Alaska during the summer was 422,137 , and 434 for the periods 19911993, 2006-2007, and 2010-2012, respectively. However, because of truncation of perpendicular distance data, the number of sightings used in the estimation of density was 381, 130, and 412 for each period. The greatest average encounter rate was observed in the period 2010-2012 (0.07 groups/km, CV=0.17) and the lowest was recorded within the period 2006-2007 (0.05 groups $/ \mathrm{km}, \mathrm{CV}=0.20)$. Expected average group sizes (Table 5) ranged from $1.37(\mathrm{CV}=0.03$, during 2010-2012) to 1.59 individuals/group ( $\mathrm{CV}=0.05$, during 1991-1993).

\section{Estimation of density and abundance}

Stratum-specific estimates of density and abundance of harbor porpoise in Southeast Alaska during the summer are summarized in Table 6. Overall, density was similarly high in the earliest (1991-1993, density (D) $=0.06, C V=0.13)$ and the latest $(2010-2012, D=0.06$, $\mathrm{CV}=0.10$ ) periods. In contrast, density declined by half during the period 2006-2007 ( $D=0.03, C V=0.20$ ). Overall estimates of abundance indicated a significant decline in the numbers of Southeast Alaska harbor porpoise from the levels observed in the early $1990 \mathrm{~s}$ $(N=1076,95 \% \mathrm{CI}=910-1272)$ to the mid-2000s $(N=604$, 95\% CI=468-780) a drop that was followed by a significant increase in the early 2010 s $(N=975,95 \%$ CI $=857-$ $1109)$ when the population reached numbers similar to those observed 20 years earlier (Table 6, Fig. 6).

Regions of higher density were consistently found near Glacier Bay and Icy Strait (region 1; the northern region of the study area) and around Zarembo Island and the town of Wrangell (region 5; the southern region of the study area), with mean densities in these 2 regions nearly 2 and 4 times greater, respectively, than the mean overall density of harbor porpoise in Southeast Alaska. Abundance in these 2 regions corresponded to $75-88 \%$ of the overall harbor porpoise abundance in the study area (Table 6), but trends in abundance differed between them. Although region 5, with Zarembo Island and Wrangell, showed a pattern similar to the one seen in the whole of Southeast Alaska, that is to say, they showed a significant decline from the early 1990 s to the mid-2000s followed by a significant in- 

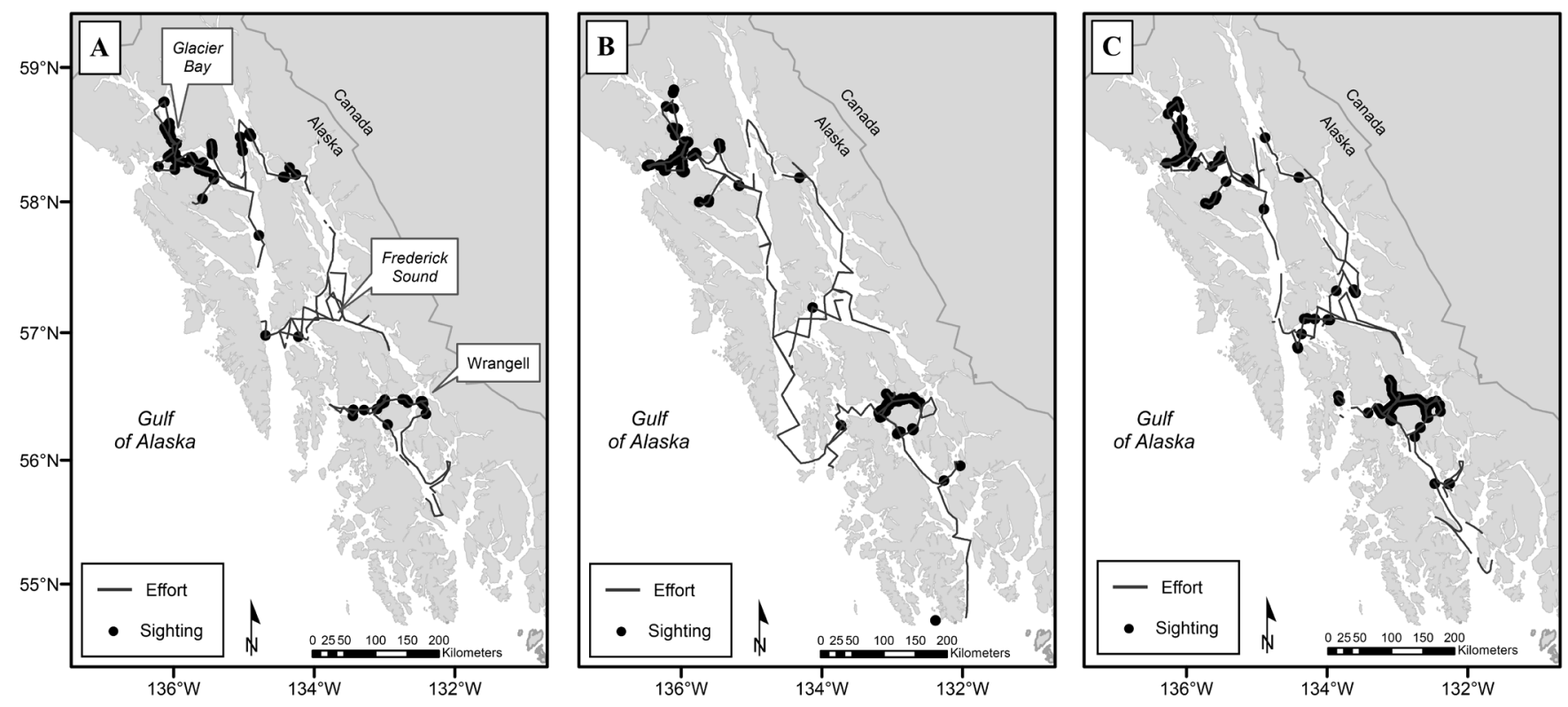

Figure 4

Maps with locations of sightings of harbor porpoise (Phocoena phocoena) and completed tracklines for line-transect surveys conducted in the inland waters of Southeast Alaska during summer in (A) 2010, (B) 2011, and (C) 2012.

crease in the early $2010 \mathrm{~s}$, abundance in region 1 , with Glacier Bay and Icy Strait, remained relatively stable during the 22-year period of this study (Table 6, Fig. 6).

\section{Discussion}

\section{Estimation of abundance}

Overall abundance was found to vary among survey periods in this 22-year study (1991-2012). The abundance $(N=1076)$ in the early 1990 s in the first survey period was relatively high, lower for the period 2006-2007 $(N=604)$ and higher again for the period 2010-2012 $(N=975)$. Because the surveys conducted in this study covered a long period of time, they were subject to some changes in methods that could affect the abundance estimates. In addition, multiple factors could have affected the sightability and identification of harbor porpoise groups, and these factors are discussed below.

To the best of our ability, we kept survey effort comparable throughout the years. With the exception of the 2007 survey, during which effort was reduced because of a 3-day mechanical breakdown and fog conditions encountered throughout various regions of the survey area, effort remained fairly consistent and only minor changes were made in trackline and coverage because of adverse weather conditions, ship mechanical breakdowns, or cruise duration. However, the number of biologists who participated in the survey varied over the 22 -year study period from 4 to 6 due to either the lack of vessel accommodations or NOAA restrictions. Both experienced and inexperienced observers were used

\section{Table 3}

Most supported models of detection probability and estimates of detection probability of harbor porpoise (Phocoena phocoena) in Southeast Alaska during the periods 1991-1993, 2006-2007, and 2010-2012. hn=half normal; hr=hazard rate; Beaufort=Beaufort sea state; $\mathrm{CV}=$ coefficient of variation; $P=$ detection probability.

\begin{tabular}{lccc}
\hline Year & $\begin{array}{c}\text { Detection } \\
\text { probability model }\end{array}$ & $P$ & $\mathrm{CV}(P)$ \\
\hline $1991-1993$ & $\mathrm{hn}+$ Beaufort & 0.51 & 0.04 \\
$2006-2007$ & $\mathrm{hr}$ & 0.61 & 0.08 \\
$2010-2012$ & $\mathrm{hn}+$ Beaufort & 0.47 & 0.04 \\
& & & \\
\hline
\end{tabular}

and some individuals participated in several different surveys and one observer participated in all surveys.

Laake et al. (1997) showed that observer experience affects their ability to detect harbor porpoise in aerial surveys; inexperienced observers miss porpoise groups 2-3 times more than experienced observers. We assumed when comparing experienced with experienced observers that the same pattern would occur during vessel surveys. However, inexperienced observers can also have difficulty both with correctly estimating group size and with accurately identifying a species (NMML, unpubl. data ${ }^{6}$ ). Average group sizes did not

\footnotetext{
${ }^{6}$ NMML (National Marine Mammal Laboratory). 2010. Unpubl. data. Alaska Fish. Sci. Cent., Natl. Mar. Fish. Serv., NOAA, 7600 Sand Point Way NE, Seattle, WA.98115-6349.
} 


\section{Table 4}

Sightings $(N)$ of harbor porpoise (Phocoena phocoena) and group encounter rates (ER; groups/km) during surveys conducted in summer in Southeast Alaska inland waters during the periods 1991-1993, 2006-2007, and 2010-2012. CV=coefficient of variation.

\begin{tabular}{|c|c|c|c|c|c|c|c|c|c|c|}
\hline \multirow[b]{2}{*}{ Region } & \multirow[b]{2}{*}{ Region name } & \multicolumn{3}{|c|}{$1991-1993$} & \multicolumn{3}{|c|}{$2006-2007$} & \multicolumn{3}{|c|}{$2010-2012$} \\
\hline & & $\mathrm{N}$ & ER & $\mathrm{CV}$ & $\mathrm{N}$ & ER & $\mathrm{CV}$ & $\mathrm{N}$ & ER & $\mathrm{CV}$ \\
\hline 1 & Cross Sound, Icy Strait, and Glacier Bay & 177 & 0.15 & 0.12 & 71 & 0.14 & 0.29 & 160 & 0.14 & 0.13 \\
\hline 2 & Lynn Canal and Stephens Passage & 22 & 0.03 & 0.25 & 7 & 0.02 & 0.39 & 12 & 0.02 & 0.42 \\
\hline 3 & Frederick Sound & 25 & 0.02 & 0.28 & 10 & 0.02 & 0.38 & 11 & 0.01 & 0.51 \\
\hline 4 & Upper and Lower Chatham Strait & 16 & 0.02 & 0.29 & 3 & 0.01 & 0.51 & 4 & 0.01 & 0.00 \\
\hline 5 & Sumner Strait, Wrangell and Zarembo Island & 132 & 0.16 & 0.25 & 39 & 0.09 & 0.28 & 214 & 0.19 & 0.14 \\
\hline 6 & Clarence Strait to Ketchikan & 9 & 0.02 & 0.42 & - & - & - & 5 & 0.01 & 0.51 \\
\hline Total & & 381 & 0.06 & 0.12 & 130 & 0.05 & 0.20 & 412 & 0.07 & 0.17 \\
\hline
\end{tabular}

differ over the years, indicating that observer experience was not an issue.

Although experienced observers can readily discern the profile differences between a surfacing harbor porpoise and a slow rolling Dall's porpoise (Phocoenoides dalli), accurate species identification can prove difficult for an inexperienced observer. Occasionally, a vertical spray of water, termed a "pop splash," occurs as the porpoise breaks the water surface to breathe (Taylor and Dawson, 1984). This vertical spray of water generated by a fast-moving harbor porpoise can, at times, be confused with the characteristic spray associated with a rooster-tailing Dall's porpoise. Within the 2 major regions where harbor porpoise concentrated, Dall's porpoise sightings were either rare or very limited in numbers (Dahlheim et al., 2009). The percentage of unidentified porpoise varied across survey years from $0 \%$ to $16 \%$ of the total number of porpoise seen. Of particular interest is that the percentages of unidentified porpoise were lowest (0-3\%) during the mid-2000s, when the steepest abundance declines were noted.

The experience level of observers varied during this multiyear study. However, on the basis of low variation in group size, low overlap of harbor and Dall's porpoise distribution, and the rate of unidentified porpoise sightings over the study period, the potential biases that result from observer variability are not a significant factor in the abundance estimates.

Harbor porpoise are small, have no visible blow, and have a very low profile in the water. These features are well-known constraints in visual detection of this species (e.g., Hammond et al., 2002). Sighting cues can be very subtle, and observers can easily miss sighting an animal even in the best of conditions. The majority of the surveys in our study were conducted in Beaufort sea states between 0 and 3 and that condition is reflected in the sighting data. Under these relatively good conditions, 99\% of the sightings were collected. Nonetheless, models with a Beaufort category were selected in 2 out of the 3 periods, indicating that higher sea states significantly reduced the sightability of porpoise.

Over the 22-year period, 5 different vessels were used, but ship height did not influence detection of

\section{Table 5}

Average expected group size, E(S), for harbor porpoise (Phocoena phocoena) during surveys conducted in inland waters of Southeast Alaska during the summer season of the periods 1991-1993, 2006-2007, and 2010-2012. CV=coefficient of variation

\begin{tabular}{|c|c|c|c|c|c|c|c|}
\hline \multirow[b]{2}{*}{ Region } & \multirow[b]{2}{*}{ Region name } & \multicolumn{2}{|c|}{$1991-1993$} & \multicolumn{2}{|c|}{ 2006-2007 } & \multicolumn{2}{|c|}{ 2010-2012 } \\
\hline & & $\mathrm{E}(\mathrm{S})$ & $\mathrm{CV}$ & $\mathrm{E}(\mathrm{S})$ & $\mathrm{CV}$ & $\mathrm{E}(\mathrm{S})$ & $\mathrm{CV}$ \\
\hline 1 & Cross Sound, Icy Strait, and Glacier Bay & 1.6 & 0.06 & 1.73 & 0.06 & 1.41 & 0.06 \\
\hline 2 & Lynn Canal and Stephens Passage & 1.49 & 0.10 & 1.57 & 0.17 & 1.24 & 0.07 \\
\hline 3 & Frederick Sound & 1.74 & 0.10 & 2.30 & 0.19 & 1.73 & 0.14 \\
\hline 4 & Upper and Lower Chatham Strait & 1.39 & 0.08 & 1.33 & 0.21 & 1.50 & 0.00 \\
\hline 5 & Sumner Strait, Wrangell, and Zarembo Island & 1.53 & 0.04 & 1.31 & 0.05 & 1.36 & 0.03 \\
\hline 6 & Clarence Strait to Ketchikan & 1.61 & 0.16 & 0.00 & 0.00 & 1.00 & 0.00 \\
\hline Total & & 1.56 & 0.03 & 1.59 & 0.05 & 1.37 & 0.03 \\
\hline
\end{tabular}



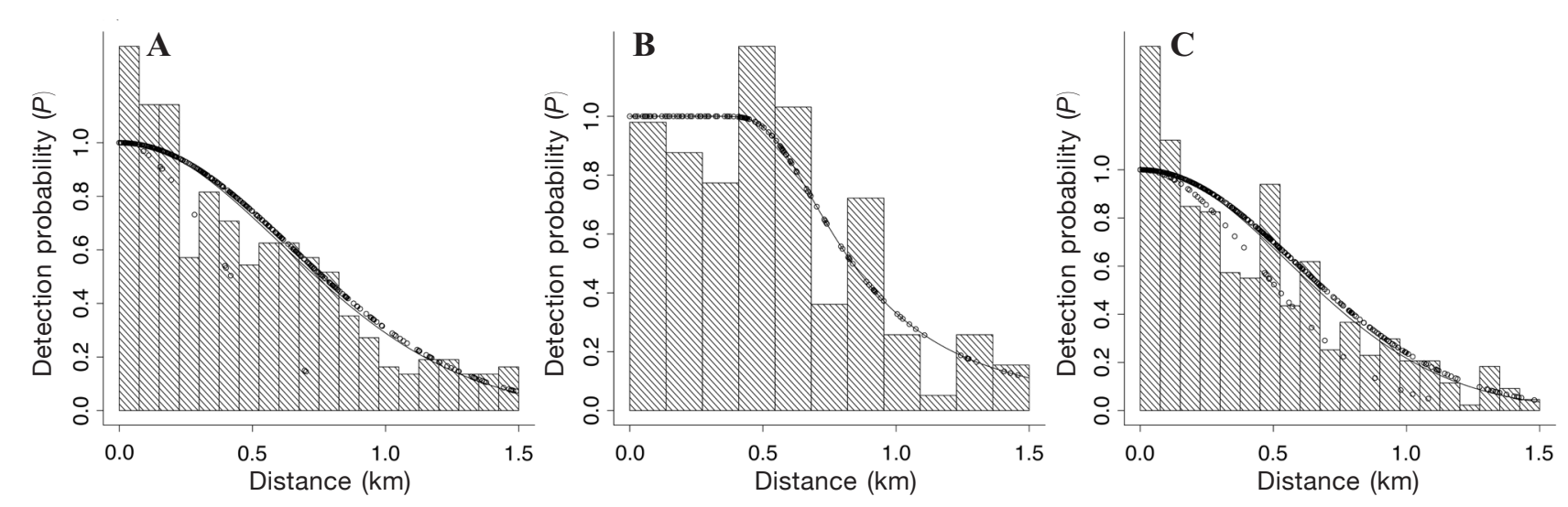

Figure 5

Detection probability models that fit perpendicular distance data collected during surveys of harbor porpoise (Phocoena phocoena) in Southeast Alaska for the following periods and models: (A) 1991-1993, half normal (hn)+Beaufort sea state; (B) 2006-2007, hazard rate; and (C) 2010-2012, hn+Beaufort sea state.

harbor porpoise, possibly because most groups were observed well within the maximum detection range provided by each ship. Animal responses may have varied on the basis of the noise profiles transmitted by these different platforms. If animals move toward or away from the survey platform during line-transect surveys, density estimates will be over- or underestimated, respectively. Palka and Hammond (2001) reported that North Atlantic harbor porpoise avoided the survey platform. However, Williams and Thomas (2007) reported that responsive movement toward or away from survey platforms was not pronounced for harbor porpoise that occupied the coastal waters of British Columbia. During our investigations, we did not observe harbor porpoise responding to our survey platform; however, quantitative data that addressed porpoise avoidance or attraction were not collected.

It is unlikely that we missed areas with high densities of harbor porpoise given the extent of our spa- tial coverage and the long-term nature of our study. In addition to the 8 summer surveys reported here (in 1991-1993, 2006-2007, 2010-2012), we also conducted 5 line-transect surveys each in the spring and fall (Table 1). Some areas typically not covered during our line-transect surveys (e.g., when we were off effort while entering bays and inlets to anchor for the night, finding shelter from storms, or conducting studies on killer whales; see Dahlheim and White, 2010) did not reveal any other regions of high porpoise densities. In addition, between 1994 and 2005, 24 more vessel surveys, during which line-transect methods were not carried out throughout this study area, found no other areas of high porpoise densities (Dahlheim et al., 2009). An aerial study conducted in 1997 (Hobbs and Waite, 2010) included some additional survey areas in Southeast Alaska but also did not reveal any other locations with high densities of harbor porpoise. Interviews with other researchers, local residents, and fishermen famil-

\section{Table 6}

Summer density (D; individuals $/ \mathrm{km}^{2}$ ) and abundance $(N$; number of individuals) of harbor porpoise (Phocoena phocoena) from surveys conducted in the inland waters of Southeast Alaska during the periods 1991-1993, 2006-2007, and 2010-2012. $\mathrm{CV}=$ coefficient of variation.

\begin{tabular}{|c|c|c|c|c|c|c|c|c|c|c|}
\hline \multirow[b]{2}{*}{ Region } & \multirow[b]{2}{*}{ Region name } & \multicolumn{3}{|c|}{$1991-1993$} & \multicolumn{3}{|c|}{$2006-2007$} & \multicolumn{3}{|c|}{$2010-2012$} \\
\hline & & $\mathrm{D}$ & $N$ & $\mathrm{CV}$ & $\mathrm{D}$ & $N$ & $\mathrm{CV}$ & $\mathrm{D}$ & $N$ & $\mathrm{CV}$ \\
\hline 1 & Cross Sound, Icy Strait, and Glacier Bay & 0.15 & 342 & 0.14 & 0.13 & 297 & 0.31 & 0.14 & 332 & 0.14 \\
\hline 2 & Lynn Canal and Stephens Passage & 0.03 & 65 & 0.24 & 0.02 & 35 & 0.44 & 0.02 & 40 & 0.42 \\
\hline 3 & Frederick Sound & 0.03 & 81 & 0.32 & 0.02 & 64 & 0.41 & 0.01 & 30 & 0.54 \\
\hline 4 & Upper and Lower Chatham Strait & 0.02 & 68 & 0.31 & 0.01 & 26 & 0.56 & 0.01 & 25 & 0.04 \\
\hline 5 & Sumner Strait, Wrangell, and Zarembo Island & 0.16 & 461 & 0.25 & 0.06 & 182 & 0.29 & 0.18 & 526 & 0.15 \\
\hline 6 & Clarence Strait to Ketchikan & 0.02 & 60 & 0.45 & 0.00 & 0 & 0.00 & 0.01 & 21 & 0.49 \\
\hline Total & & 0.06 & 1076 & 0.13 & 0.03 & 604 & 0.20 & 0.06 & 975 & 0.10 \\
\hline
\end{tabular}




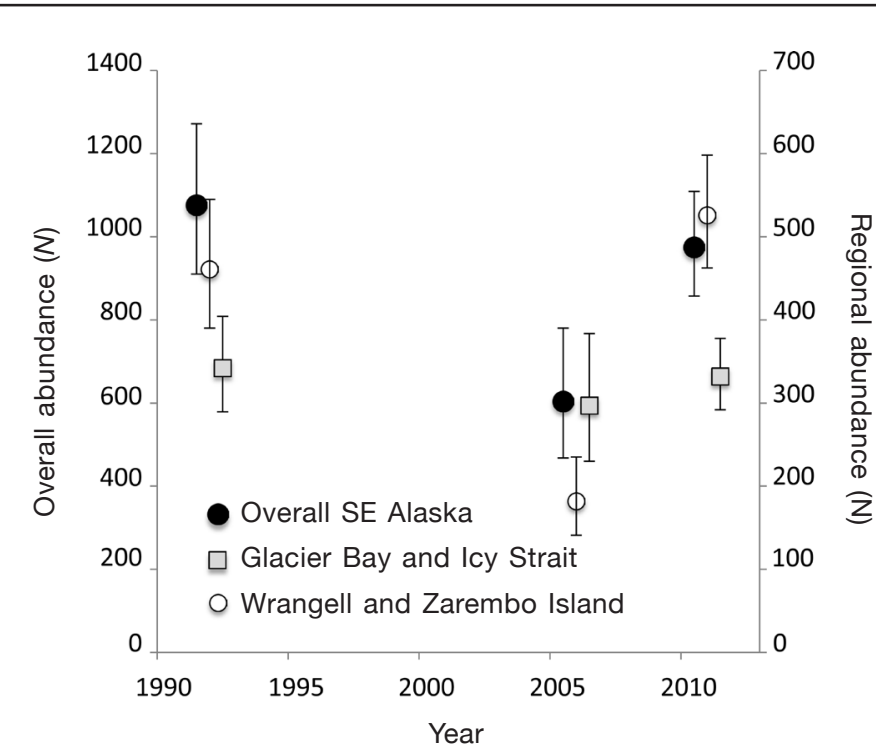

Figure 6

Estimates for overall and regional abundance of harbor porpoise (Phocoena phocoena) from surveys conducted in Southeast Alaska during the periods 1991-1993, 2006-2007, and 2010-2012. Note the significant declines (nonoverlapping confidence intervals) in the estimates provided for overall Southeast Alaska and for the region that included Wrangell and Zarembo Island in the mid-2000s and the relatively stable trend over the 22-year study period (1991-2012) for the region that included Glacier Bay and Icy Strait. Error bars indicate $95 \%$ confidence intervals.

iar with these waters also revealed no other areas of major porpoise concentrations.

Because of the patterns of clumped distribution observed for harbor porpoise, if we did miss an entire region where animals were concentrated both temporally and spatially, that omission would significantly affect our abundance estimate for that particular year. However, by pooling data across sequential years, we reduced the variance resulting from the naturally patchy distribution of harbor porpoise.

The abundance estimates we derived for harbor porpoise in Southeast Alaska are likely biased low for 2 major reasons. We did not sample all areas used by harbor porpoise in inlands waters of Southeast Alaska. This region encompasses an area of $27,808 \mathrm{~km}^{2}$, but only $17,665 \mathrm{~km}^{2}$ were actually surveyed. Although there is limited evidence that any of the regions that were not surveyed corresponded with high-density porpoise habitats, the occurrence of a small number of animals in these regions would lead to an underestimated abundance. Another important source of negative bias in results of harbor porpoise studies comes from animals that are missed along the trackline, that is from the violation of the assumption of $g(0)=1$. Previous studies have documented the importance of obtaining an estimation of the proportion of animals missed along the trackline (i.e., the proportion derived from $g[0]$ experiments) to compute absolute estimates of abundance (Barlow, 1988; Palka, 1995, 1996). These studies have shown that approximately $20-50 \%$ of harbor porpoise groups are missed.

If $g(0)$ correction factors obtained from other vessel studies (Barlow, 1988; Palka, 1995) are used to adjust for animals missed by observers, the total number of harbor porpoise in Southeast Alaska may be 1.5-2.0 times greater than the numbers reported here. However, the actual value of the correction factor for our study is unknown and may vary considerably on the basis of many aspects and circumstances that affect porpoise sightability, including visual search protocols of observers, weather and visibility conditions, survey platform, behavior of porpoise, and density of animals in different regions (Laake and Borchers, 2004; Laake et al., 1997; Palka, 1995). Clearly, $g(0)$ experiments are needed to obtain absolute abundance of harbor porpoise in Southeast Alaska. Ideally, these estimates should be survey-specific in order to assess whether and how very different survey teams and conditions affect the estimation of animals missed along the tracklines.

Before the surveys conducted in 2011 and 2012, a trend analysis, completed to include the 1991-1993, 2006-2007, and 2010 surveys, indicated a high probability of a decline in porpoise numbers ranging from $2 \%$ to $4 \%$ per year for the whole study area (Zerbini et al.7). However, when data from 2011 and 2012 were added to this analysis, the rate of decline over the entire study period decreased substantially and was no longer significant. The increase in abundance observed for the waters surrounding Wrangell and Zarembo Island represented a three-fold increase that is not biologically plausible given the rate at which this species reproduces. Therefore, it is likely that this increase reflected a combination of factors, including possible population growth, a shift in distribution, or the influx of porpoise from other regions (e.g., offshore waters).

It is unclear why the decline in porpoise numbers occurred between the early 1990s and the mid-2000s (Fig. 6 ) or, in fact, if this decline is real. The low abundance in 2006 and 2007 cannot be explained by reduced survey effort (i.e., 2 survey years versus 3 survey years for the periods 1991-1993 and 2010-2012) because similar effort per unit of area took place where high-densities of porpoise occur for all years. Given the clumped distribution of harbor porpoise in the study area, it

\footnotetext{
${ }^{7}$ Zerbini, A., M. E. Dahlheim, J. Waite, A. Kennedy, P. R. Wade, and P. J. Clapham. 2011. Evaluation of population declines of harbor porpoise (Phocoena phocoena) in Southeast Alaska inland waters. In Book of abstracts: 19th biennial conference on the biology of marine mammals; Tampa, FL., 28 November-2 December. Society for Marine Mammalogy, Moss Landing, CA.
} 
is possible but unlikely, given the multiple years involved and the overall extent of the area coverage in our study, that a large grouping of animals was missed during a survey period. One explanation is that part of the population may have moved outside our study area (e.g., offshore waters) because of shifts in prey availability and abundance. Without knowing whether porpoise shift their distribution or what might drive it if they do (e.g., prey preferences or oceanographic conditions), we cannot determine whether porpoise movement patterns are a factor in the observed downward trend. In addition, a change in porpoise numbers may also be dependent upon year-to-year variations in habitat suitability, increased predation, increased mortality from bycatch, or a combination of all these factors.

When examined on a regional scale, abundance was relatively consistent throughout the survey period in the northern region that included Glacier Bay. In contrast, a significant downward trend in abundance was estimated for the southern region that included the waters surrounding Wrangell and Zarembo Island between the early 1990s and the mid-2000s, and an increase was observed for that region as of 2010. Of particular interest is that porpoise numbers declined only in regions where salmon (Oncorhynchus spp.) and Pacific herring net fisheries operate. Certainly, bycatch has been shown to be a significant source of porpoise mortality in other geographic areas (Gaskin, 1984; Read and Gaskin, 1988; Woodley and Read, 1991; Read et al., 1993) and may, in fact, be responsible for the downward trend observed in our data for the mid-2000s. We are unable, however, to attribute the decline in the mid-2000s to incidental takes in the net fisheries given that interaction data are not available. Regardless of the reasons for that decline, further studies are necessary to understand the possible causes of the variability observed in our study in the abundance of harbor porpoise in inland waters off Southeast Alaska.

\section{Insights into population structure}

As currently defined (see Introduction), the Southeast Alaska stock of harbor porpoise occurs from Dixon Entrance to Cape Suckling, including all inland and coastal waters within this region (total area $=106,087 \mathrm{~km}^{2}$ ). Studies that have addressed stock structure of harbor porpoise in Alaska are either not available or based on limited sampling from a particular area (Rosel et al., 1995; Chivers et al., 2002). Outside Alaska, research has shown that harbor porpoise stock structure is of a finer scale than that of the stock structure reflected in the Alaska stock assessment report for 2011 (Allen and Angliss, 2012). Stock discreteness in the eastern North Pacific was, for example, analyzed by using mitochondrial DNA from samples collected in California, Washington, and British Columbia but from only one sample from Alaska (Rosel, 1992). Results of our initial investigation indicated little interbreeding of harbor porpoise along the western coast of North America.
Further genetic testing by Rosel et al. (1995, 1999) showed that harbor porpoise in both the eastern North Pacific and North Atlantic were not panmictic and that movement was sufficiently restricted resulting in genetic differences. Furthermore, Chivers et al. (2002), using both mitochondrial and nuclear (microsatellite) DNA, examined the intraspecific structure of harbor porpoise that inhabited the eastern North Pacific and reported similar findings. These studies revealed statistically significant genetic differentiation, indicating demographic independence of fairly small subunits within the population.

Additional evidence that harbor porpoise restrict their movements has been obtained from both contaminant research and satellite tagging studies. Investigations on the pollutant loads of harbor porpoise from California to the Canadian border (Calambokidis and Barlow, 1991) also suggest restricted movement patterns of harbor porpoise. Pollutant studies produced similar results in the North Atlantic (Westgate and Tolley, 1999). Satellite-tagging operations conducted in Puget Sound, Washington, have shown that porpoise movements were fairly localized and did not occur between Neah Bay (at the entrance of the Strait of Juan de Fuca) and the San Juan Islands; these 2 regions are separated by approximately $150 \mathrm{~km}$ of continuous open waterways $\left(\right.$ Hanson $\left.^{8}\right)$.

During our study, harbor porpoise distribution was clumped in 2 major areas that were consistent throughout the 22-year period: the waters of Glacier Bay and Icy Strait and the waters surrounding Wrangell and Zarembo Island, including the adjacent waters of eastern Sumner Strait (northern and southern regions, respectively; also see Dahlheim et al., 2009). These regions are separated by a distance of approximately $400 \mathrm{~km}$. If harbor porpoise within the inland waters of Southeast Alaska behave in the same manner as harbor porpoise elsewhere have been reported to behave (i.e., movements are locally restricted), then a low level of mixing would be expected, indicating the potential for reproductive isolation between the 2 regions. The physical character of this region (e.g., hundreds of islands and a complexity of waterways) may also limit frequent movements of harbor porpoise between the 2 regions.

The difference in abundance trends between the northern and southern regions of the study area provides additional evidence that these 2 regions, where consistent porpoise concentrations have occurred over 2 decades, represent regions of population structuring for this species within the inland waters of Southeast Alaska. Of utmost concern is that incidental takes within a small region (e.g., Wrangell and Zarembo Island) could severely affect undefined localized stocks of harbor porpoise that could easily go undetected unless stock structure is identified. On a larger scale, given the wide distribution of harbor porpoise throughout

\footnotetext{
${ }^{8}$ Hanson, B. 2013. Personal commun. Northwest Fish. Sci Cent., 2725 Montlake Blvd. East, Seattle, WA 98115-2097.
} 
Alaska waters, it is likely that several other regional and subregional populations exist within the 3 currently designated stocks.

In summary, the results of our analysis with data from surveys conducted between the years 1991 and 2010 led us to believe that numbers of harbor porpoise within the inland waters of Southeast Alaska declined significantly, highlighting a potentially important conservation issue. With the inclusion of data from surveys conducted in 2011 and 2012, our analysis indicates that if a decline occurred, then the population may be recovering. It is not clear whether the observed decline and subsequent increase in abundance represent a true decline in the population or a reflection of variable local abundance related to interannual differences in prey availability, habitat suitability, or other factors.

The overall changes in abundance of harbor porpoise observed in this study could have remained undetected were it not for the long time series of this research, clearly demonstrating both the value and need for multiyear studies on long-lived mammals, such as cetaceans. Understanding the distribution, abundance, and population trends of a given species is essential for conservation efforts to be effective. On the basis of our study, we hypothesize that harbor porpoise populations within the inland waters of Southeast Alaska contain structure. Although this structure is currently unclear, we suggest that different stocks probably exist within this region. A proper assessment of the status of the harbor porpoise stock or stocks in Southeast Alaska requires a combination of research approaches, i.e., conducting coastal and inland surveys at the same time to evaluate stock abundance, exploring correction factors for this species (e.g., $g[0]$ experiments), performing genetic studies (to fully define stock structure), and using satellite telemetry (to understand porpoise movements within or across current stock boundaries).

\section{Acknowledgments}

Our appreciation is extended to the various captains and crew of the John N. Cobb and of the FV Steller, FV Northwest Explorer, RV Medeia, and RV Aquila. We thank numerous observers for their many hours of survey effort. This manuscript was improved by the critical reviews of B. Taylor and J. Laake (Southwest Fisheries Science Center, La Jolla, California). We thank H. Braham, D. DeMaster, S. Moore, P. Wade, and P. Clapham for their continued support of this research over a 22-year period.

\section{Literature cited}

Allen, B. M., and R. P. Angliss.

2012. Alaska marine mammal stock assessments, 2011. NOAA Tech. Memo. NMFS-AFSC-234, 288 p.

Barlow, J.

1988. Harbor porpoise, Phocoena phocoena, abundance estimation for California, Oregon, and Washington: I. Ship surveys. Fish. Bull. 86:417-432.

2006. Cetacean abundance in Hawaiian waters estimated from a summer/fall survey in 2002. Mar. Mamm. Sci. 22:446-464. Article

Barlow, J., S. L. Swartz, T. C. Eagle, and P. R. Wade.

1995. U.S. marine mammal stock assessments: guidelines for preparation, background, and a summary of the 1995 assessments. NOAA Tech. Memo. NMFSOPR-6, $73 \mathrm{p}$.

Buckland, S. T., D. R. Anderson, K. P. Burnham, J. L. Laake, D. L. Borchers, and L. Thomas.

2001. Introduction to distance sampling: estimating abundance of biological populations, 432 p. Oxford Univ. Press, Oxford, UK.

Burnham, K. P., and D. R. Anderson.

2002. Model selection and multi-model inference: a practical information-theoretic approach, $2^{\text {nd }}$ ed., $488 \mathrm{p}$. Springer-Verlag, New York.

Calambokidis, J. and J. Barlow.

1991. Chlorinated hydrocarbon concentrations and their use for describing population discreteness in harbor porpoises from Washington, Oregon, and California. In Marine mammal strandings in the United Sates: proceedings of the second marine mammal stranding workshop; Miami, 3-5 December 1987 (J. E. Reynolds III, and D. K. Odell, eds.), p. 101-110. NOAA Tech. Rep. NMFS 98.

Carretta, J. V., B. L. Taylor, and S. J. Chivers.

2001. Abundance and depth distribution of harbor porpoise (Phocoena phocoena) in northern California determined from a 1995 ship survey. Fish. Bull. 99:29-39.

Chivers, S. J., A. E. Dizon, P. J. Gearin, and K. M. Robertson.

2002. Small-scale population structure of eastern North Pacific harbour porpoises (Phocoena phocoena) indicated by molecular genetic analyses. J. Cetacean Res. Manage. 4:111-122.

Dahlheim, M. E., and P. A. White.

2010. Ecological aspects of transient killer whales Orcinus orca as predators in southeastern Alaska. Wildl. Biol. 16:308-322. Article

Dahlheim, M., A. York, R. Towell, J. Waite J., and J. Breiwick. 2000. Harbor porpoise (Phocoena phocoena) abundance in Alaska: Bristol Bay to Southeast Alaska, 19911993. Mar. Mamm. Sci. 16:28-45. Article

Dahlheim, M. E., P. A. White, and J. M. Waite.

2009. Cetaceans of Southeast Alaska: distribution and seasonal occurrence. J. Biogeogr. 36:410-426. Article

Gaskin, D. E.

1984. The harbor porpoise Phocoena phocoena (L) regional populations, status, and information on direct and indirect catches. Rep. Int. Whaling Comm. 34:569-586.

Hammond, P. S., P. Berggren, H. Benke, D. L. Borchers, A. Collet, M. P. Heide-Jørgensen, S. Heimlich, A. R. Hiby, M. F. Leopold, and N. Øien.

2002. Abundance of harbour porpoise and other cetaceans in the North Sea and adjacent waters. J. Appl. Ecol. 39:361-376. Article

Hobbs, R. C., and J. M. Waite.

2010. Abundance of harbor porpoise (Phocoena phocoena) in three Alaskan regions, corrected for observer errors due to perception bias and species misidentification, and corrected for animals submerged from view. Fish. Bull. 108:251-267. 
Innes, S., M. P. Heide-Jørgensen, J. L.Laake, K. L. Laidre, H. J. Cleator, P. Richard, and R. E. A. Stewart.

2002. Surveys of belugas and narwhals in the Canadian High Arctic in 1996. NAMMCO Sci. Pub. 4:169-190.

Jefferson, T. A., and B. E. Curry.

1994. A global review of porpoise (Cetacea: Phocoenidae) mortality in gillnets. Biol. Conserv. 67:167-183. Article

Laake, J. L., and D. L. Borchers.

2004. Methods for incomplete detection at distance zero. In Advanced distance sampling (S. T. Buckland, D. R. Anderson, K. P. Burnham, J. L. Laake, D. L. Borchers, and L. Thomas, eds.), p. 108-189. Oxford Univ. Press, Oxford, UK.

Laake, J. L., J. Calambokidis, S. D. Osmek, and D. J. Rugh. 1997. Probability of detecting harbor porpoise from aerial surveys: estimating $g(0)$. J. Wildl. Manage. 61:6375. [Available at website.]

Leatherwood, S., and R. R. Reeves.

1978. Porpoises and dolphins. In Marine mammals of the eastern North Pacific and arctic waters (D. Haley, ed.), p. 97-111. Pacific Search Press, Seattle.

Lerczak, J. A., and R. C. Hobbs.

1998. Calculating sighting distances from angular readings during shipboard, aerial, and shorebased marine mammal surveys. Mar. Mamm. Sci. 14:590-598. Article

Marques, F. F. C., and S. T. Buckland.

2003. Incorporating covariates into standard line transect analyses. Biometrics 59:924-935. [Available at website.]

Palka, D.

1995. Abundance estimate of the Gulf of Maine harbor porpoise. Spec. Issue Rep. Int. Whaling Comm. $16: 27-50$

1996. Effects of Beaufort sea state on the sightability of harbor porpoises in the Gulf of Maine. Rep. Int. Whaling Comm. 46:575-582.

Palka, D. L., and P. S. Hammond.

2001. Accounting for responsive movement in line transect estimates of abundance. Can. J. Fish. Aquat. Sci. 58:777-787. Article

Read, A. J., and D. E. Gaskin.

1988. Incidential catch of harbor porpoises by gill nets. J. Wildl. Manage. 52:517-523. [Available at website.]
Read, A. J.

1994. Interactions between cetaceans and gillnet and trap fisheries in the Northwest Atlantic. Spec. Issue Rep. Int. Whaling Comm. 15:133-147.

Read, A. J., S. D. Kraus, K. D. Bisack, and D. Palka.

1993. Harbor porpoise and gill nets in the Gulf of Maine. Conserv. Biol. 7:189-193. [Available at website.]

Rosel, P. E.

1992. Genetic population structure and systematic relationships of some small cetaceans inferred from mitochondrial DNA sequence variation. Ph.D. diss., $191 \mathrm{p}$. Univ. Calif. San Diego, CA.

Rosel, P. E., A. E. Dizon, and M. G. Haygood.

1995. Variability of the mitochondrial control region in populations of the harbour porpoise, Phocoena, on interoceanic and regional scales. Can. J. Fish. Aquat. Sci. 52:1210-1219. Article

Rosel, P. E., S. C. France, J. Y. Wang, and T. D. Kocher.

1999. Genetic structure of harbour porpoise Phocoena phocoena populations in the northwest Atlantic based on mitochondrial and nuclear markers. Mol. Ecol. 8:S41-S54. Article

Taylor, B. L., and P. K. Dawson.

1984. Seasonal changes in density and behavior of harbor porpoise (Phocoena phocoena) affecting census methodology in Glacier Bay National Park, Alaska. Rep. Int. Whaling Comm. 34:479-483.

Westgate, A. J., and K. A. Tolley.

1999. Geographical differences in organochlorine contaminants in harbour porpoises Phocoena phocoena from the western North Atlantic. Mar. Ecol. Prog. Ser. 177:255-268. Article

Williams, R., and L. Thomas.

2007. Distribution and abundance of marine mammals in the coastal waters of British Columbia, Canada. J. Cetacean Res. Manage. 9:15-28.

Woodley, T. H., and A. J. Read.

1991. Potential rates of increase of a harbor porpoise, Phocoena phocoena, population subjected to incidental mortality in commercial fisheries. Can. J. Fish. Aquat. Sci. 48:2429-2435. Article

Zerbini, A. N., J. M. Waite, J. L. Laake, and P. R. Wade.

2006. Abundance, trends and distribution of baleen whales off Western Alaska and the central Aleutian Islands. Deep-Sea Res. I 53:1772-1790. Article 